\title{
Nutrient dynamics in decomposing litter from four selected tree species in Makurdi, Benue State, Nigeria
}

\author{
Thomas Okoh ${ }^{1 *}$ (D) and Esther Edu ${ }^{2}$
}

\begin{abstract}
Background: Nutrient release during litter decomposition was investigated in Vitex doniana, Terminalia avecinioides, Sarcocephallus latifolius, and Parinari curatellifolius in Makurdi, Benue State Nigeria (January 10 to March 10 and from June 10 to August 10, 2016). Leaf decomposition was measured as loss in mass of litter over time using the decay model $W_{t} / W_{0}=e^{-{ }^{k d} t}$, while $\mathrm{Kd}=-\frac{1}{t} \ln \left(\frac{W_{t}}{W_{0}}\right)$ was used to evaluate decomposition rate. Time taken for half of litter to decompose was measured using $T_{50}=\ln { }^{2} / k$; while nutrient accumulation index was evaluated as $N A I=\left(\frac{\omega t}{\omega 0 X}\right)$.

Results: Average mass of litter remaining after exposure ranged from $96.15 \mathrm{~g}$, (V. doniana) to $78.11 \mathrm{~g}$, (S. lafolius) in dry (November to March) and wet (April to October) seasons. Decomposition rate was averagely faster in the wet season (0.0030) than in the dry season (0.0022) with P. curatellifolius (0.0028) and T. avecinioides (0.0039) having the fastest decomposition rates in dry and wet seasons. Mean residence time (days) ranged from 929 to 356, while the time (days) for half the original mass to decompose ranged from 622 to 201 (dry and wet seasons). ANOVA revealed highly significant differences $(p<0.01)$ in decomposition rates and exposure time (days) and a significant interaction $(p<0.05)$ between species and exposure time in both seasons.

Conclusion: Slow decomposition in the plant leaves implied carbon retention in the ecosystem and slow release of $\mathrm{CO}_{2}$ back to the atmosphere, while nitrogen was mineralized in both seasons. The plants therefore showed effectiveness in nutrient cycling and support productivity in the ecosystem.
\end{abstract}

Keywords: Nutrient dynamics, Litter decomposition, Decay coefficient, Nutrient accumulation index, Turnover rate

\section{Introduction}

Litter decomposition is a major pathway in the process of nutrient return to the soil. Several studies on litter decomposition have provided useful information on the rates and pattern of decomposition and nutrient release in various ecosystems and the factors affecting species rate of decomposition (Negrete-Yankelevich et al. 2008; Vivanco and Austin 2008; Ayres et al. 2009). Litter nutrient quality such as nitrogen and lignin content (Aerts 1997), vegetation, and litter types have been suggested as factors affecting litter decomposition (Gholz et al. 2000; Prescott et al. 2000; Cornelissen et al. 2007) as well as

\footnotetext{
* Correspondence: thomasokoh@gmail.com

${ }^{1}$ Department of Botany, Federal University of Agriculture, Makurdi, Nigeria Full list of author information is available at the end of the article
}

climatic factors such as temperature and precipitation (O'Neill et al. 2003; Karberg et al. 2008). Aponte et al. (2012) stated that, the controlling factors of early decomposition and nutrient release differ from those of slow decomposing litter and build-up of soil organic matter.

Slow decomposition rates result in build-up of organic matter and nutrient stocks in soil; however, fast decomposition rates increase the nutrient availability for plant intake (Isaac and Nair 2005).

The leaf decomposition rate is a measure of the speed at which litter is decomposed in the ecosystem. Residence time gives a measure of how long the litter remains in the ecosystem before decomposition. Nutrient accumulation index indicates if nutrients (nitrogen,

(c) The Author(s). 2019 Open Access This article is distributed under the terms of the Creative Commons Attribution 4.0 International License (http://creativecommons.org/licenses/by/4.0/), which permits unrestricted use, distribution, and reproduction in any medium, provided you give appropriate credit to the original author(s) and the source, provide a link to the Creative Commons license, and indicate if changes were made. The Creative Commons Public Domain Dedication waiver (http://creativecommons.org/publicdomain/zero/1.0/) applies to the data made available in this article, unless otherwise stated. 
carbon) are released into the environment (mineralization) or retained (accumulation) in decomposing leaves. Turnover rate indicates mass of litter lost through decomposition since decomposing leaves are trapped in litter bags and excludes other ecological processes that export leaves. Half-life is the time taken for half the mass of the litter to decompose.

Vitex doniana Joris de Wolf (Verbenaceae) is a small to medium-sized tree, $11 \mathrm{~m}$ tall; with single bole often slightly fluted at the base $(90-160 \mathrm{~cm})$. Leaves are opposite, digitately compound. Inflorescence is axillary cyme up to $10 \mathrm{~cm}$ long and $16 \mathrm{~cm}$ wide. Flowers are bisexual, zygomorphic, and pentamerous; while the fruit is a drupe with 4, non-endospermous seeds (Orwa et al. 2009). The plant is wide spread in savanna and in wetter areas at lower altitudes, in secondary and dry forests. The fruit and fresh leaves are edible, while medicinal uses include treatment for anemia; the root is used as treatment for gonorrhea. The wood is used for wood fire and charcoal (FAO 1983).

Terminalia avicennioides (Combretaceae) is a small tree, 7-10 $\mathrm{m}$ tall. The plant is wide spread in savanna and in wetter areas at lower altitudes, in secondary and dry forests (FAO 1983). The crown is open and the bark is deeply cracked and corky, dark grey to black. Leaves are alternate, simple, and entire; petiole $1-3 \mathrm{~cm}$ long, with blade narrowly elliptical $(10-20 \mathrm{~cm} \times 3-7 \mathrm{~cm}$. Inflorescence is a raceme, bearing bisexual flowers, regular, and pentamerous. The plant occurs across West Africa and has several anthropogenic uses such as for chewing stick, wood fire, and as dye (FAO 1983).

Sarcocephalus latifolius (JE Sm.) EA. Bruce (Rubiaceae) is a shrub, with multi stems and open canopy. The leaves are broad, and smooth white flowers are terminal and aggregated into a head-like cyme of small whitish flowers joined by their calyces with a syncarpuous fruit. The plant shows wide distribution in tropical Africa. The fleshy fruits and leaves are edible fodder; the wood is a source of wood fire and the bark yields tannins used in dyeing (FAO 1983).

Parinari curatellifolia (Chrysobalanaceae) is a large, evergreen, spreading tree $(20 \mathrm{~m})$ with a single bare stem and rough bark. Leaves are alternate, simple, and dark green on top. Flowers are axillary, bisexual, and pentamerous. Fruits are oval $(5 \times 3.5 \mathrm{~cm})$ and orange-yellow when ripe. The fruits are edible and are occasionally utilized for the brewing of alcoholic beverages, while the wood provides good source wood fire (FAO 1983).

The highlighted species dominate the vegetation of the study area. The species are widespread in open savanna with moderate rainfall and high temperature. The species thrive naturally on sandy soils and fallow land (Tyowua et al., 2013). The species, among other aforementioned uses, are used for mulching by farmers and, because of their dominant status, understanding their rate of decomposition would therefore provide better insights into their contribution to nutrient cycling. The aim of this research was to investigate litter decomposition and nutrient dynamics in Vitex doniana, Terminalia avecinioides, Sarcocephallus latifolius, and Parinari curatellifolia, and the specific objectives were to evaluate the litter turnover rate, residence time, half-life, and the nutrient accumulation index in the leaves of the selected species.

\section{Materials and methods \\ Study area}

The research was carried out at the Agan open forest area of Makurdi, Benue State (January 10 to March 10 and from June 10 to August 10, 2016). The area falls within the Guinea Savanna agro ecological zone of Nigeria (latitudes $7038^{\prime}$ and 70 50' North of the Equator and longitude $8024^{\prime}$ and $8038^{\prime}$ East of the Greenwich Meridian). The relief is generally low lying, ranging from below 90 to $150 \mathrm{~m}$ above sea level. Three soil types (alluvial, clayey loam, and sandy) predominate, with a total land mass of $3,993.3 \mathrm{~km}^{2}$ and divided by the River Benue into North and South Banks, respectively (Kogbe 1989; Tyowua et al., 2013) (Fig. 1). The region is a tropical area with alternating wet (April to October) and dry (November to March) seasons and an annual average precipitation of $1240-1440 \mathrm{~mm}$. Temperature generally is high during the day especially in March and April, with daily maximum and minimum temperatures between 37 and $16{ }^{\circ} \mathrm{C}$ (NIMET 2015, 2016) (Fig. 2). The study area is a hub for agricultural activity and annual bush burning; hence, it is a mixture of natural and human-managed mosaics of different tree and grass species (Tyowua et al., 2013).

\section{Data collection}

The litterbag technique was adopted for evaluating litter decomposition at the soil surface as it allowed for selective entry of microfauna and reduce particle loss during decomposition (Robertson and Paul 1999). Senescent leaves were harvested (plucked) directly from the tree. The leaves were rinsed with de-ionized water and air dried for $24 \mathrm{~h}$, to remove dust particles, and placed in litter bags kept under the same tree. Twenty grams $(20 \mathrm{~g})$ of senescent leaves from five litterbags of each plant were oven dried at $80{ }^{\circ} \mathrm{C}$ to constant mass and used to determine the mean initial mass of dry leaves in the bags. Eight litterbags ( $1 \mathrm{~mm}$ mesh size) were placed under each plant (on the floor) and tethered with nylon rope. A total of 160 bags were distributed among the four species (each species in five replicates, each replicate with eight litterbags). A litterbag was collected from 
A

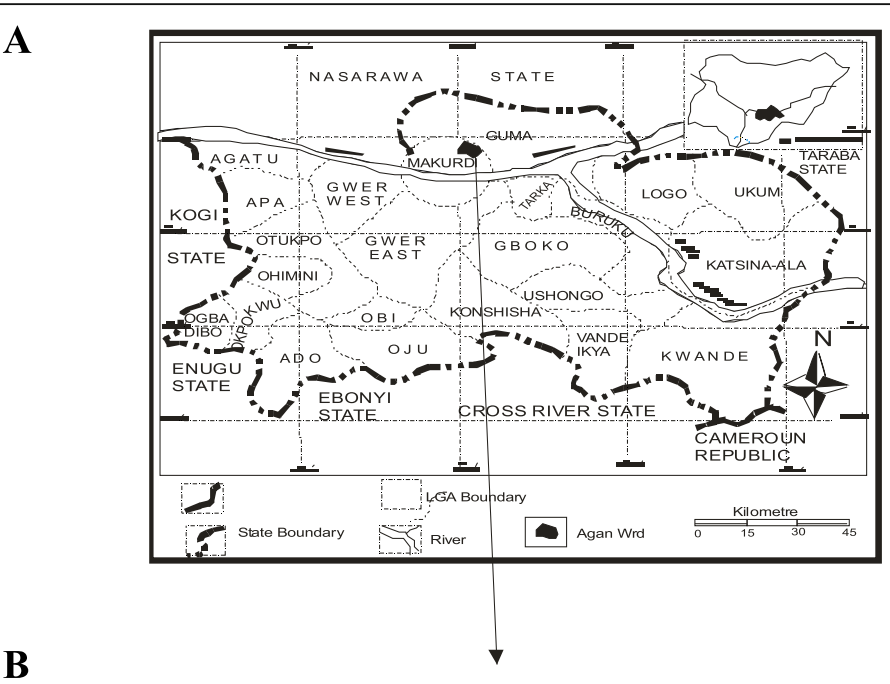

B

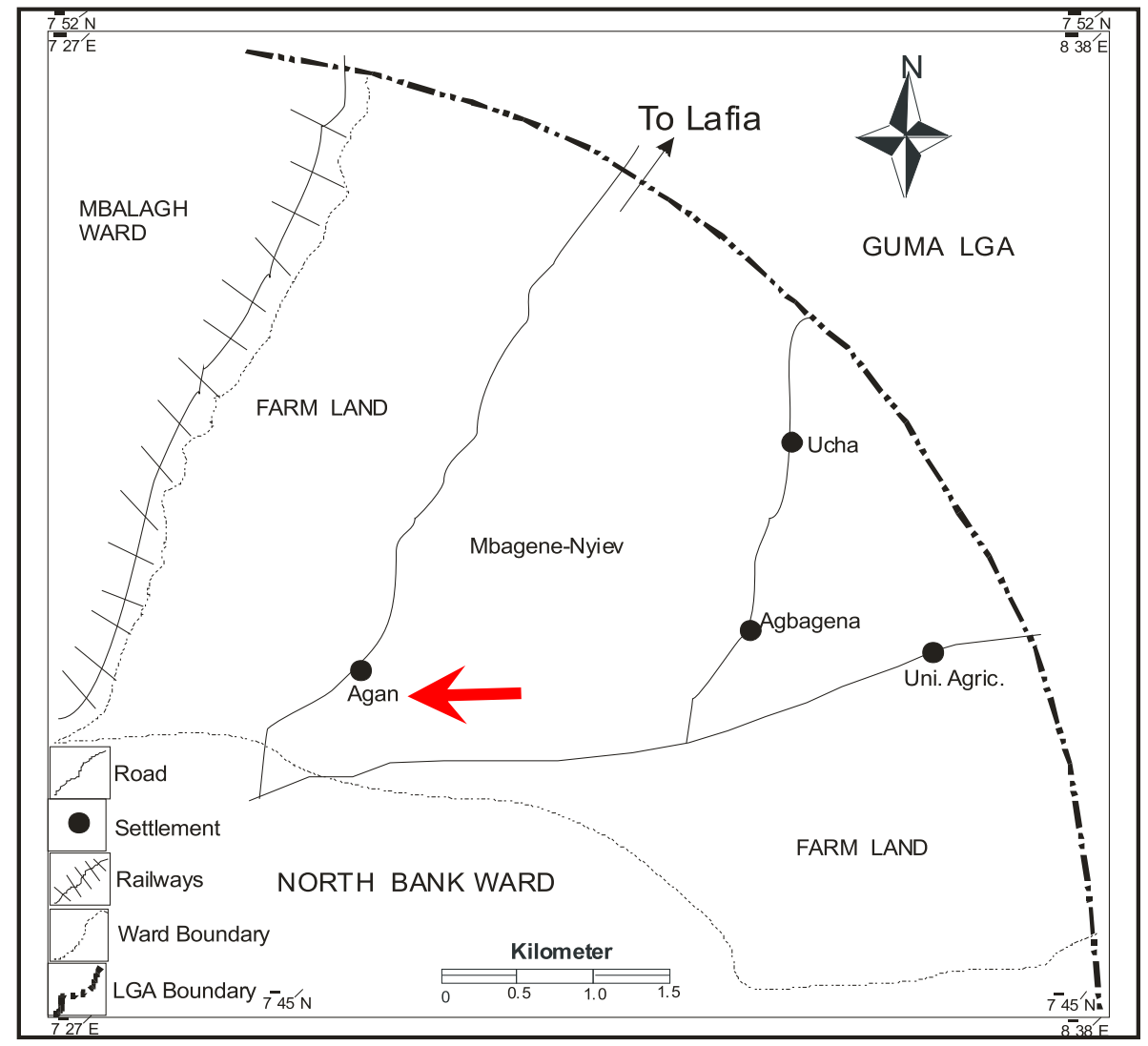

Fig. 1 Map of study area (a). Map of Benue State, North-Central Nigeria; (b). Map of Study Site (indicated by red arrow) in Makurdi, Benue State, Nigeria. Source: Ministry of Lands and Survey Makurdi, Benue State, Nigeria

each plant (20 litterbags) at 14, 28, 42 , and 56 days after initial placement. Thus, a total of 80 bags were retrieved and analyzed. After each collection, the litter was gently rinsed (to get rid of soil), oven dried at $80{ }^{\circ} \mathrm{C}$ to constant mass, and finely ground in a mill for nutrient analysis. The experiment was carried out in both wet and dry seasons.

\section{Data analysis}

Graphs of mean mass of litter remaining after time $t$, as percentage of initial dry mass were obtained for all species. The negative single exponential decay model by Olson (2007) and Aldair et al. (2010) was used to evaluate the relationship between percentage mass of litter remaining and sampling time for all species using the 


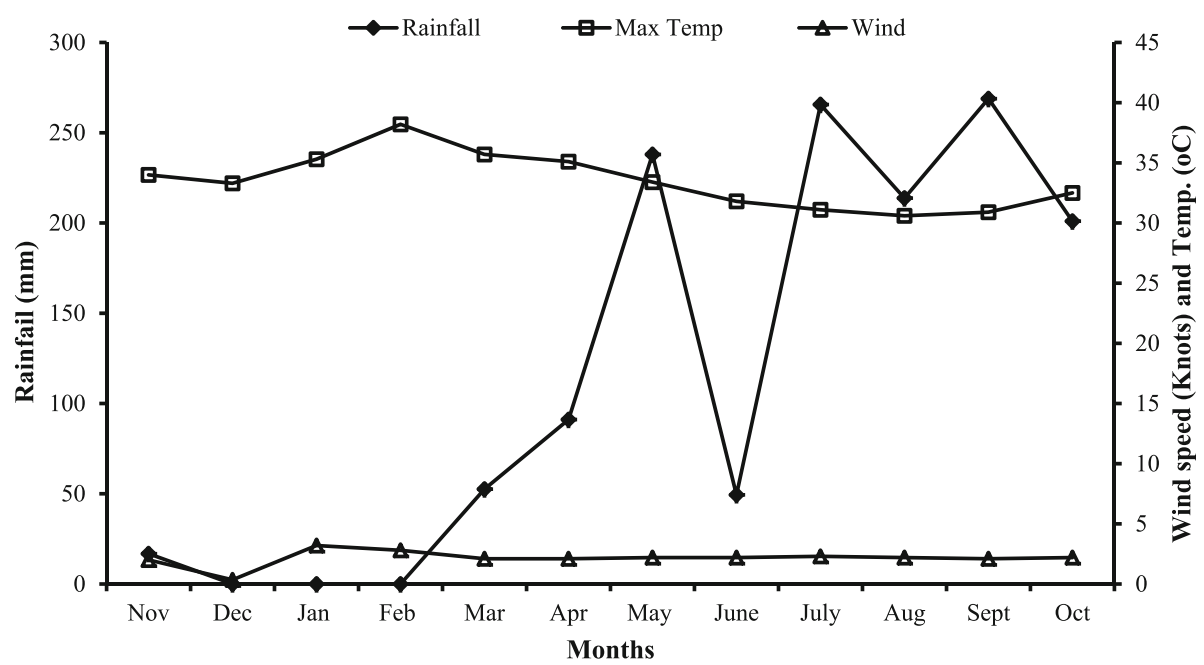

Fig. 2 Climate map of Makurdi, Benue State, Nigeria indicating mean monthly rainfall, temperature, and wind speed across the wet (April to October) and dry (November to March) seasons during the study period (2016)

equation $W_{t} / W_{0}=e^{-{ }^{k d} t}$; where $W_{0}=$ initial dry mass; $W_{\mathrm{t}}=$ mass remaining at time $t ; K_{d}=$ decomposition coefficient in days $\left(\mathrm{d}^{-1}\right)$ and is derived as follows:

$$
\begin{aligned}
& \log _{\mathrm{e}}\left(W_{t} / W_{0}\right)=\log _{\mathrm{e}}{ }^{-K}{ }_{d}^{t} \\
& \log _{\mathrm{e}}\left(W_{t} / W_{0}\right)=-K_{d}^{t} \\
& K_{d}=-{ }^{1} / t\left(\log _{\mathrm{e}} W_{t}-\log _{\mathrm{e}} W_{0}\right) ; \mathrm{Kd}=-\frac{1}{t} \operatorname{In}\left(\frac{W t}{W 0}\right)
\end{aligned}
$$

Two-way analysis of variance (ANOVA) was used to evaluate the effects of species and exposure time on the rate of decomposition in all the species, with species and exposure time as the main factors. The time taken for the half of the initial material to decompose $\left(t_{50}\right)$ was evaluated using equation; $t_{50}=\ln 2 / k$; where $\ln =$ natural logarithm; $K=$ decomposition rate.

\section{Net changes in nutrients}

Nutrient accumulation index (NAI) for each species was calculated in order to establish a net mineralization or accumulation of carbon and nitrogen in the decomposing leaves, using equation NA $=\left(\frac{\omega t X t}{\omega \mathrm{O} X \mathrm{o}}\right)$. (Harmon et al., 1986); where, $W_{t}=$ the dry weight of the leaf litter at time $t, X_{t}=$ the nutrient concentration of the leaf litter at time $t$, the initial dry weight of leaf litter and $X_{0}=$ the initial concentration of nutrient in the leaf litter.

An NAI value of 1.0 indicates that the decomposed leaf litter contains the same mass of the element " $\mathrm{X}$ " when the leaf litter was placed in the litter bag; NAI < 1.0 indicates net mineralization of the element from the decaying leaf litter and NAI > 1.0 indicates net assimilation of the element by the decaying leaf litter. Relationships between exposure time and nutrient contents (carbon and nitrogen contents) in decomposing leaves were determined by correlation and regression analyses (Table 1).

\section{Results}

\section{Decomposition rate}

Average mass of litter remaining (g) ranged from $96.15 \mathrm{~g}$ ( $V$. doniana) to $78.11 \mathrm{~g}$ (S. latifolius) in both seasons respectively (Fig. 3). Mean rate of decomposition $\left(k_{d}\right)$ was

\begin{tabular}{|c|c|c|c|}
\hline Comparison & Pearson correlation $r$ & $p$ value & Equation \\
\hline \multicolumn{4}{|l|}{ Dry season } \\
\hline Exposure time $v$ nitrogen & -0.228 & $0.022^{*}$ & $y=1.47+-0.02 \times x$ \\
\hline Exposure time $v$ carbon & -0.266 & $0.008^{* *}$ & $y=30.34+-1 . \times 17 \times x$ \\
\hline \multicolumn{4}{|l|}{ Wet season } \\
\hline Exposure time $\vee$ nitrogen & -0.807 & $0.000^{* *}$ & $y=1.52+-0.05 \times x$ \\
\hline Exposure time $v$ carbon & -0.517 & $0.000^{* *}$ & $y=31.43+-2 \times x$ \\
\hline
\end{tabular}

Table 1 Correlation and regression coefficients and equations showing relationship between exposure time and nitrogen and carbon decomposition

${ }^{* *} p<0.001$ statistically significant at $99 \%$ confidence interval; ${ }^{*} p<0.005$ statistically significant at $95 \%$ confidence interval 

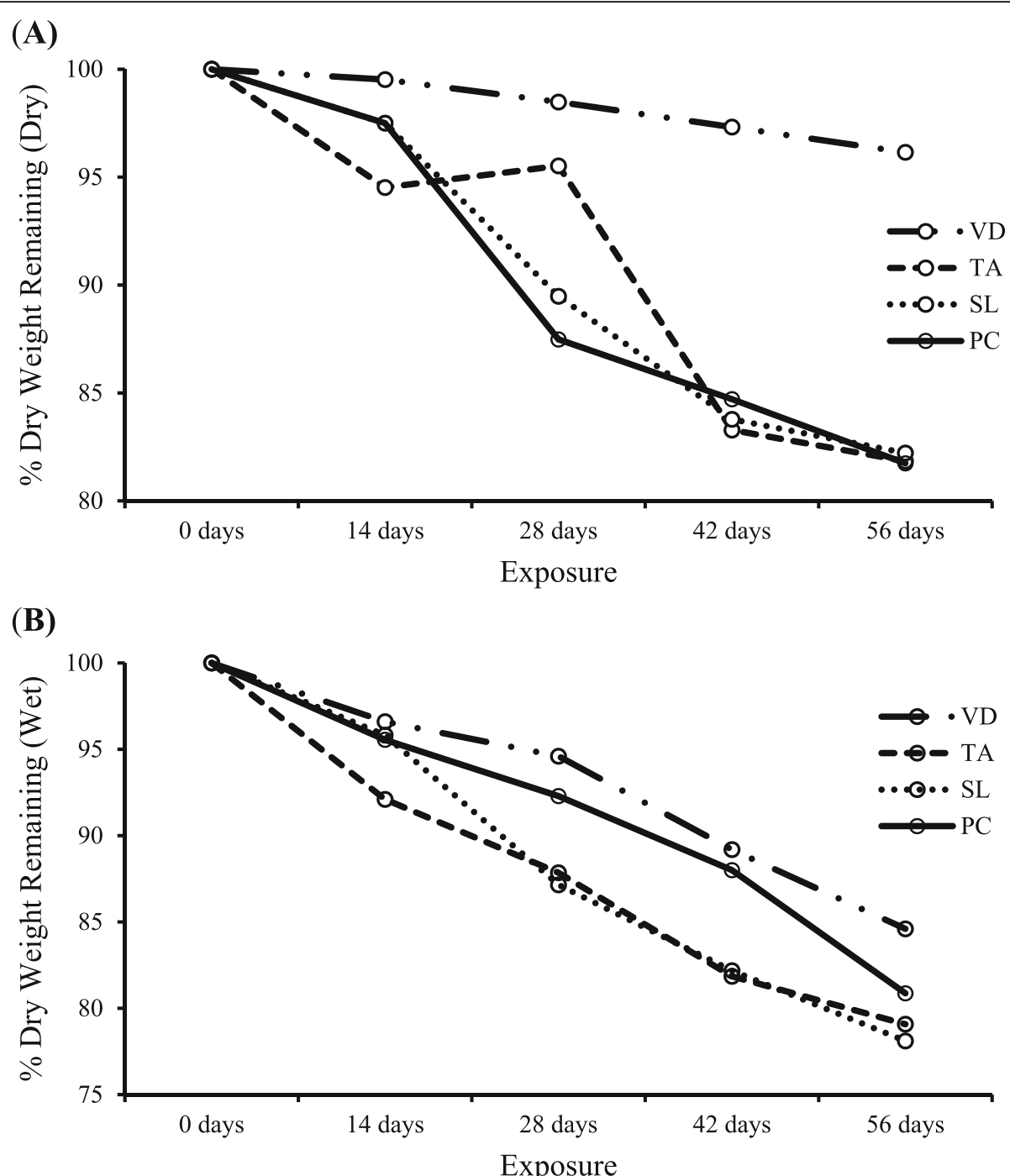

Fig. $3 \%$ dry weight remaining for four species. a Dry season. b Wet season. VD, Vitex doniana; TA, Terminalia avicennioides; SL, Sarcocephalus latifolius; PC, Parinari curatellifolia

faster in the wet season $\left(0.0030 \mathrm{~g} \mathrm{~d}^{-1}\right)$ than in dry season $\left(0.0022 \mathrm{~g} \mathrm{~d}^{-1}\right)$, with $P$. curatellifolius $(0.0028 \mathrm{~g}$ $\left.\mathrm{d}^{-1}\right)$ and $T$. avecinioides $\left(0.0039 \mathrm{~g} \mathrm{~d}^{-1}\right)$ having the fastest rates of decomposition in the dry and wet seasons (Fig. 4). ANOVA revealed highly significant differences $(p<0.01)$ in decomposition rates and exposure time (days) and a significant interaction $(p<0.05)$ between species and exposure time in both seasons (Table 1).

\section{Turnover rate}

Turnover rates in the dry season ranged from 0.0027 ( $T$. avecinioides) and 0.0004 ( $V$. doniana) and from 0.0039 ( $T$. avecinioides) and 0.002 ( $V$. doniana) in the wet season. Mean projected residence time ranged from 2500 days ( $V$. doniana) to 357 days ( $P$. curatellifolius) in the dry season and from 491 days ( $V$. doniana) to 256 days (T. avecinioides) in the wet season (Fig. 4). The minimum time (days) taken for half the original mass of litter to decompose (half-life) varied between 1732 days ( $V$. doniana) and 178 days (T. avecinioides) in dry and wet seasons respectively.

\section{Nutrient dynamics}

Carbon and nitrogen contents were generally higher in the dry season than in the wet season (Fig. 5). Nutrient accumulation index (NAI) generally revealed a net mineralization of nitrogen while carbon was immobilized in both seasons respectively (Fig. 6). There were negative relationships $(p<0.001)$ between exposure time (days) and nitrogen and between exposure time and carbon contents in both seasons (Table 1). 

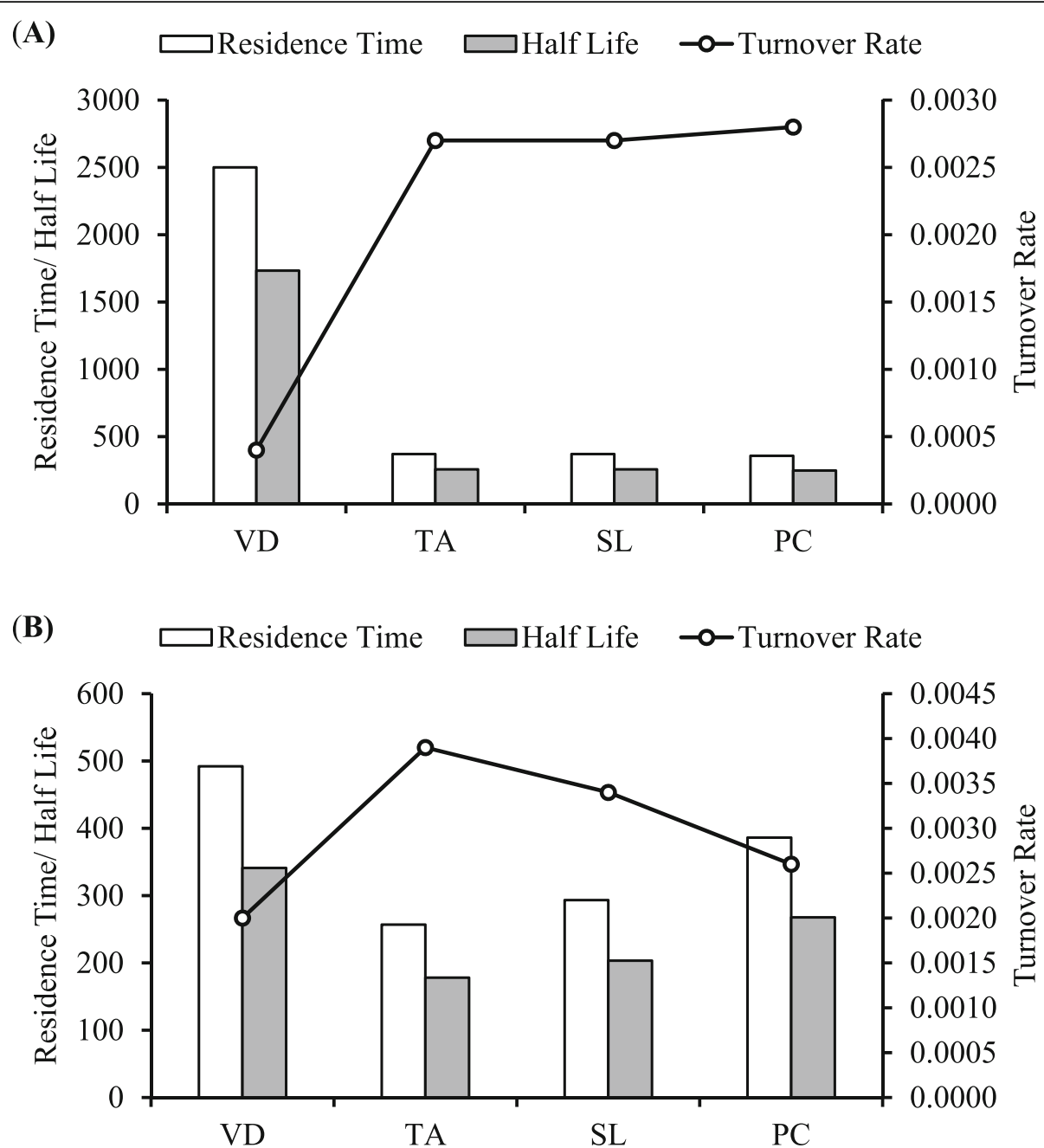

Fig. 4 Residence time, half-life, and turnover rate of four species. a Dry season. b Wet season. VD, Vitex doniana; TA, Terminalia avicennioides; SL, Sarcocephalus latifolius; PC, Parinari curatellifolia

\section{Discussion}

The faster rate of decomposition in the wet season suggested the possible interactive effects of climatic conditions that stimulated the activity of soil fauna (Gautam et al. 2016; Xu et al. 2011), microbial activity, and loss of labile carbon through the carbon pool. Furthermore, in the dry season, inadequate moisture might have slowed down the decomposition process. Aponte et al. (2012), Negrete-Yankelevich et al. (2008), stated that, trees provide specific requirements which in turn determine the availability of decomposer communities that drive the decomposition process. Hence, placing the leaves (in litterbags) under tree canopy in this study probably enhanced the rate of decomposition than in naturally decaying leaves. Variation in species mean decay coefficients $\left(K_{d}\right)$ in the study could possibly be due to differences in species litter quality and nutrient type, as suggested by other researchers (Gholz et al. 2000;
Prescott et al. 2000; Cornelissen et al. 2007). Turnover rates indicate loss through decomposition since the decomposing leaves are trapped. The study site is an open Savanna plagued with high farming activities, grazing animals, turbulent wind, bush burning, seasonal surface run-offs, as well as macro-consumers. The species with high decomposition rate will therefore enhance organic matter retention supporting agricultural production in the area.

Negative relationship between mean percentage of nutrients (nitrogen and carbon) and exposure time in both seasons suggests that decomposition was not affected by the length of exposure but based on other factors such as microbial utilization of litter and litter quality that enhanced decomposition rate. The initial drop in litter quantity during the first phase of decomposition and the occasional rise in nutrient contents of decomposing litter observed in this study are in line with the general 

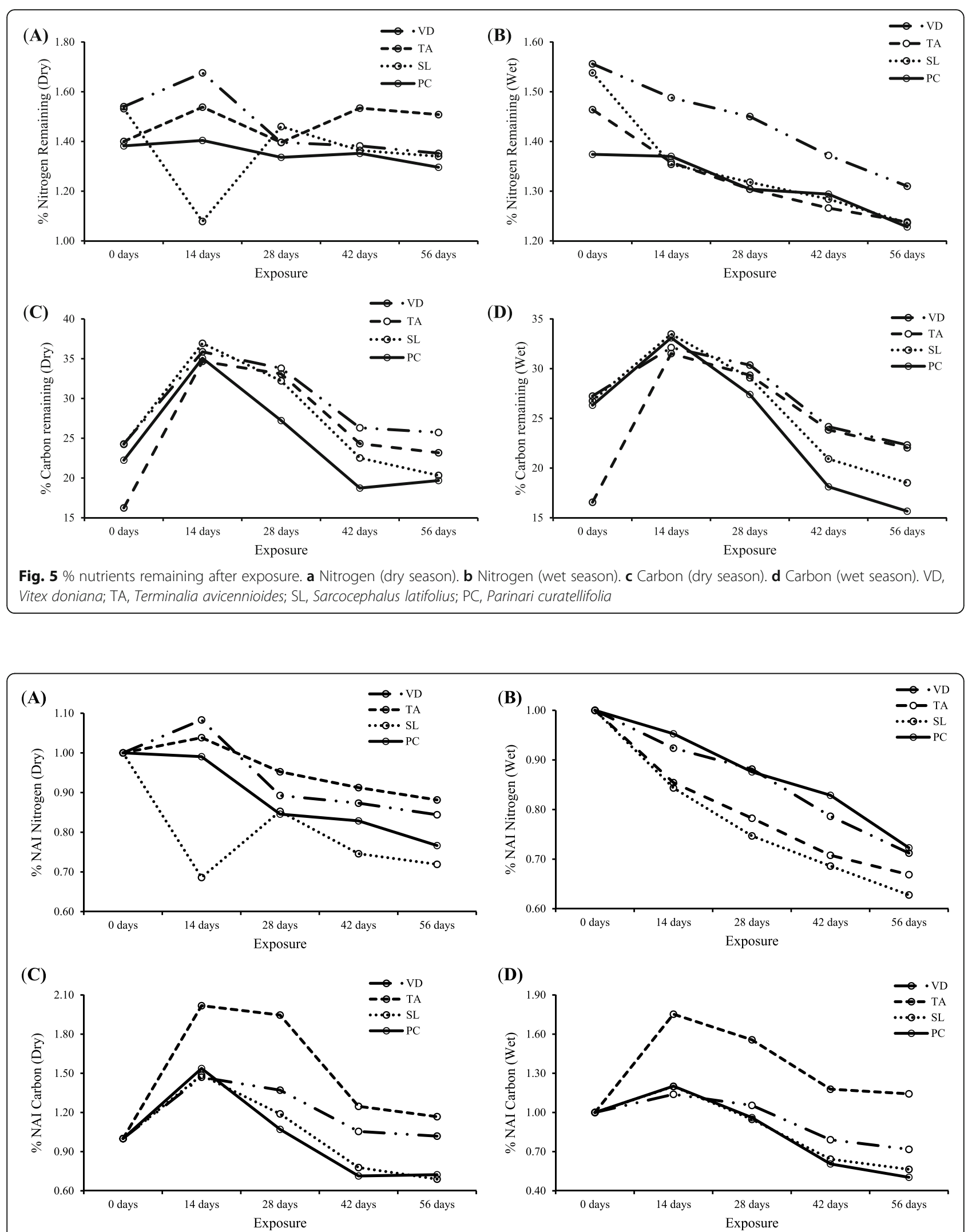

Fig. 6 \% nutrient accumulation index (NAI) in the species leaves following exposure. a Nitrogen (dry season) b Nitrogen (wet season) c Carbon (dry season) d Carbon (wet season). VD, Vitex doniana; TA, Terminalia avicennioides; SL, Sarcocephalus latifolius; PC, Parinari curatellifolia 
model of litter decomposition which includes initial leaching of nutrients, nutrient immobilization, and nutrient release into the soil.

The significant variations $(p<0.01)$ between nutrient contents in the decomposing leaves and exposure time in both seasons (Table 1; Fig. 5) suggested that different nutrients have different patterns of release in time (Girisha et al. 2003; Aponte et al. 2011; Augusto et al. 2002). This is possibly due to species differences in leaf composition, oxygen availability, soil characteristics, and microbial utilization as suggested by other researchers (Mitchell et al. 2007; Aponte et al., 2011; Austin and Vivanco 2006). Negrete-Yankelevich et al. (2008), The tree canopies (with limited abiotic mineralization driven by solar radiation and mechanical forces) provided a home-field advantage to the decomposing leaves placed under it and supplied specific nutrients that influenced microbial populations, resulting in nutrient enrichment in the decomposing leaves (Vivanco and Austin 2008; Ayres et al. 2009; Arriaga and Maya 2007). Abugre et al. (2011) explained that, nutrient release depends on whether such nutrient is limiting or not to microbial growth. $\mathrm{He}$ further explained that when a nutrient is limiting in amount and carbon:element ratio is above critical level, such element will be accumulated resulting in immobilization, whereas, if the carbon:element ratio is below critical level the element will be released.

Nutrient accumulation index (NAI) of nitrogen and carbon (Table 1 and Fig. 6), indicated a release of nitrogen $(\mathrm{NAI}<1)$ from the decomposing leaves into the soil while carbon was immobilized or assimilated (NAI $>1$ ) probably through increased microbial population. The negative relationship between mean percentage nutrient remaining and exposure time in both seasons (Table 1) reflects microbial utilization of litter which enhanced decomposition rate and nutrient release (Gusewell and Gessner 2009).

\section{Conclusion}

The high percentage mass of initial litter remaining after exposure indicated slow decomposition which implied nutrient retention and slow release of nutrients back to the ecosystem. Net changes in nutrient (mineralization and immobilization) varied among species and seasons. Nitrogen was mineralized in both seasons, while carbon was immobilized (assimilated), supporting productivity in the system.

The species decomposition showed their ecological importance in building up organic matter for nutrient cycling in the ecosystem. It also suggested that the species litter would remain longer in the ecosystem before decomposing; hence, they are suitable for mulching activities in the study area. The species therefore showed effectiveness in nutrient cycling and enhancing productivity. Nutrient dynamics in decomposing litter could indicate whether the ecosystem is in a nutrient conservative stage. This is important particularly for the study area since agriculture is the mainstay of its economy.

\section{Acknowledgements \\ Not applicable \\ Authors' contributions \\ Design was done by both authors. TO carried out the research and the manuscript was edited by EE. Both authors read and approved the final manuscript.}

\section{Funding}

No funding was received for this research.

\section{Availability of data and materials \\ Yes}

Ethics approval and consent to participate

Not applicable

\section{Consent for publication}

The authors give their consent.

\section{Competing interests}

The authors declare that they have no competing interests.

\section{Author details}

'Department of Botany, Federal University of Agriculture, Makurdi, Nigeria. ${ }^{2}$ Department of Plant and Ecological Studies, University of Calabar, Calabar, Nigeria.

Received: 16 May 2019 Accepted: 28 November 2019

Published online: 16 December 2019

\section{References}

Abugre SC, Oti-Boateng, Yeboah MF. Litterfall and decomposition trend of Jatropha curcas L. leaves mulches under two environmental conditions. Agric Biol J North Am. 2011;2(3):462-70.

Aerts R. Climate, leaf litter chemistry and leaf litter decomposition in terrestrial ecosystems: a triangular relationship. Oikos. 1997;79:439-49.

Aldair EC, Hobbie SE, Hobbie RK. Single pool exponential decomposition models; potential pit falls in their use in ecological studies. Ecology. 2010;91:1225-36.

Aponte C, Garcia LV, Maranon T. Tree species effect on Litter decomposition and nutrient release in Mediterranean Oak forests changes over time. Ecosystems. 2012;15:1204-18.

Aponte C, Garcia LV, Perez-Ramos IM, Gutierrez E, Maranon T. Oak trees and soil interactions in Mediterranean forests: a positive feed-back model. J Vegetation Sci. 2011;22:856-67.

Arriaga L, Maya Y. Spatial variability in decomposition rates in a desert scrub of North-western Mexico. Plant Ecol. 2007;189:213-25.

Augusto L, Ranger J, Binkley D, Roth A. Impact of several common tree species of European temperate forests on soil fertility. Ann Sci. 2002;55(59):233-53.

Austin AT, Vivanco L. Plant litter decomposition in a semi-arid ecosystem controlled by photo-degradation. Nature. 2006;442:555-8.

Ayres E, Steltzer H, Berg S, Wall DH. Soil biota accelerates decomposition in highelevation forests by specializing in the breakdown of litter produced by the plant species above them. J Ecol. 2009;97:901-12.

Cornelissen JHC, Van Bodegom PM, Aerts R, Callaghan TV, Van Logtestijin RSP, Alatalo J. Global negative feed-back to climate warning responses of litter decomposition rates in cold biomes. Ecol Lett. 2007;10:619-27.

FAO (Food and Agriculture Organization). Food and fruit bearing forest species. 1: Examples from Eastern Africa. Rome: FAO Forestry Paper.44/1; 1983.

Gautam MK, Lee KS, Song BY, Lee D, Bong YS. Early-stage changes in natural 13C and $15 \mathrm{~N}$ abundance and nutrient dynamics during different litter decomposition. J Plant Res. 2016;129:463-76. 
Gholz HL, Wedin DA, Smitherman SM. Long-term dynamics of pine and hardwood litter in contrasting environments: toward a global model of decomposition. Glob Chan Biol. 2000;6:750-65.

Girisha JK, Condon LM, Clinton PW, Davis MR. Decomposition and nutrient dynamics of green and freshly fallen radiate pine (Pinus radiate) needles. Forest Ecol Manag. 2003;179:169-81.

Gusewell S, Gessner MO. N:P ratios influence litter decomposition and colonization by fungi and bacteria in microsoms. Funct Ecol. 2009;23:211-9.

Harmon ME, Franklin JF, Swanson FJ, Sollins P, Gregory SV, Lattin JD, Lienkaemper, G. W. Ecology of coarse woody debris in temperate ecosystems. In Advances in ecological research; 1986. 15, p 133-302). Academic Press.

Isaac SR, Nair MA. Biodegradation of leaf litters in the warm humid tropic of Kerala, India. Soil Biol Biochem. 2005;37:1656-64.

Karberg NJ, Neal AS, Giadina PC. Methods for estimating litter decomposition. In: Hoover CM, editor. Field Measurements for Forest Carbon Monitoring. New York: Springer Science +Business Media B.V; 2008. p. 103-11.

Kogbe CA. A brief history of geological society of Africa. Terra Nova. 1989;1(5): 399-401.

Mitchell RJ, Campbell CD, Osler GHR, Van Bergen AJ, Ross LC, Cameron CM, Cole $L$. The cascading effects birch on heather moorland: a test for the top-down control of an ecosystem engineer. J Ecol. 2007;93:540-54.

Negrete-Yankelevich S, Fragoso C, Newton A, Russell G, Heal O. Species specific characteristics of trees can determine the litter macro-invertebrate community and decomposition process below their canopies. Plant Soil. 2008;307:83-97.

NIMET (Nigerian Meteorological Agency). Annual weather bulletin of the Nigerian Meteorological Agency. Makurdi: Tactical Air Command, Nigerian Air Force; 2015.

NIMET (Nigerian Meteorological Agency). Annual weather bulletin of the Nigerian Meteorological Agency. Makurdi: Tactical Air Command, Nigerian Air Force; 2016.

O'Neill EG, Johnson DW, Ledford J. Acute seasonal drought does not permanently alter mass loss and nitrogen dynamics during decomposition of red maple litter. Global Change Biol. 2003;9:117-23.

Olson JS. Energy storage and the balance of producers and decomposers in ecological systems. Ecology. 2007:44:322-31.

Orwa C, Mutua A, Kindt R, Jamadass R, Anthony S. Agro-forestry database: a tree reference and selection guide version 4.0. Kenya: World Agroforestry Centre; 2009.

Prescott CE, Zabek LM, Stanley CL. Decomposition of broadleaf and needle litter in forests of British Columbia: influences of litter type, forest type, and litter mixtures. Can J Forest Resourc. 2000;30:1742-50.

Robertson GP, Paul EA. Decomposition and soil organic matter dynamic. In: Sale QE, Jackson RB, editors. Methods of Ecosystem Science. New York: Springer; 1999. p. 104-16.

Tyowua BT, Agbelusi EA, Dera BA. Evaluation of vegetation types and utilization in wild life park of the University of Agriculture, Markurdi, Nigeria. Greener Journal of Agricultural Science, 2013;3(1), 001-005.

Vivanco L, Austin AT. Tree species identity alters forest litter decomposition through long-term plant and soil interactions in Patagonia, Argentina. J Ecol. 2008;96:727-36.

Xu S, Liu Y, Pei Z. Litter decomposition in a subtropical plantation in Qianyanzhou, China. J Res. 2011;16:8-15.

\section{Publisher's Note}

Springer Nature remains neutral with regard to jurisdictional claims in published maps and institutional affiliations.

\section{Ready to submit your research? Choose BMC and benefit from:}

- fast, convenient online submission

- thorough peer review by experienced researchers in your field

- rapid publication on acceptance

- support for research data, including large and complex data types

- gold Open Access which fosters wider collaboration and increased citations

- maximum visibility for your research: over $100 \mathrm{M}$ website views per year

At BMC, research is always in progress.

Learn more biomedcentral.com/submissions 